Article

\title{
What Does the Evidence Tell Us about 'Thinking and Working Politically' in Development Assistance?
}

\author{
Niheer Dasandi ${ }^{1}$, Ed Laws $^{2}$, Heather Marquette ${ }^{1, *}$ and Mark Robinson ${ }^{3}$ \\ ${ }^{1}$ International Development Department, University of Birmingham, Birmingham, B15 2TT, UK; \\ E-Mails:n.dasandi@bham.ac.uk (N.D.), h.a.marquette@bham.ac.uk (H.M.) \\ 2 Overseas Development Institute, London, SE1 8NJ, UK; E-Mail: e.laws@odi.org.uk \\ ${ }^{3}$ World Resources Institute, Washington, DC 20002, USA; E-Mail: markashrobin@gmail.com \\ * Corresponding author
}

Submitted: 14 December 2018| Accepted: 27 February 2019 | Published: 5 June 2019

\begin{abstract}
This article provides a critical review of the evidence on 'thinking and working politically' (TWP) in development. Scholars and practitioners have increasingly recognised that development is a fundamentally political process, and there are concerted efforts underway to develop more politically-informed and adaptive ways of thinking and working in providing development assistance. However, while there are interesting and engaging case studies in the emerging, largely practitionerbased literature, these do not yet constitute a strong evidence base that shows these efforts can be clearly linked to more effective aid programming. Much of the evidence used so far to support these approaches is anecdotal, does not meet high standards for a robust body of evidence, is not comparative and draws on a small number of self-selected, relatively well-known success stories written primarily by programme insiders. The article discusses the factors identified in the TWP literature that are said to enable politically-informed programmes to increase aid effectiveness. It then looks at the state of the evidence on TWP in three areas: political context, sector, and organisation. The aim is to show where research efforts have been targeted so far and to provide guidance on where the field might focus next. In the final section, the article outlines some ways of testing the core assumptions of the TWP agenda more thoroughly, to provide a clearer sense of the contribution it can make to aid effectiveness.
\end{abstract}

\section{Keywords}

aid effectiveness; development assistance; donors; evidence; governance; politics; thinking and working politically

\section{Issue}

This article is part of the issue "Aid Impact and Effectiveness", edited by Rachel M. Gisselquist and Finn Tarp (UNU-WIDER, Finland).

(C) 2019 by UNU-WIDER; licensee Cogitatio (Lisbon, Portugal). This article is licensed under a Creative Commons Attribution 4.0 International License (CC BY).

\section{Introduction}

A long-standing criticism of development assistance has been its technocratic focus. This technocratic approach can be traced back to the origins of modern development assistance after the Second World War, which was in part based on the belief that 'underdevelopment is a function of a lack of resources-usually financial, but also technical or human-and that this can be tackled with a sufficient infusion of capital' (Hudson \& Dasandi, 2014, p. 239). However, the growing focus on aid effectiveness-or more specifically, the lack of aid effectiveness (see Bourguignon \& Sundberg, 2007; Doucouliagos \& Paldam, 2009; Tarp \& Hansen, 2003)has led to criticisms of the failure of aid donors to engage with the inherently political nature of the development process, criticisms that have come from various sources over an almost thirty year period (e.g. Easterly, 2006; Ferguson, 1990; Leftwich, 2000; Unsworth, 2009). From this perspective, the persistence of poor policies and weak institutions is believed to have less to do with a lack of knowledge or finance and more to do with the ac- 
tions of powerful actors, groups or collective movements who gain from existing arrangements and resist change (Leftwich, 2000).

Over the past two decades, in a bid to improve aid effectiveness, major donors have sought to engage more explicitly with the politics of the contexts in which they operate (Carothers \& de Gramont, 2013). This turn to politics by aid donors and other development organizations - which is discussed in detail by Carothers and de Gramont (2013) - has been labelled 'thinking and working politically' or 'TWP'. As Teskey (2017) points out, the exact origin of the phrase 'thinking and working politically' is uncertain. The first formal academic reference seems to be in Leftwich (2011), but there are internal Department for International Development (DFID) notes going back at least to the early 2000s that reference the key ideas (see e.g., Pycroft, 2006, 2010). ${ }^{1}$ While there is no single agreed definition, framework or set of formal tools for 'TWP', three potentially core principles of TWP have been set out: a) strong political analysis, insight and understanding; b) a detailed appreciation of, and response to, the local context; and c) flexibility and adaptability in program design and implementation (TWP Community of Practice, 2013).

In recent years, there has been a notable increase in aid programmes that explicitly reference TWP and/or what are said to be similar ideas such as 'Doing Development Differently' (DDD), problem-driven iterative adaptation (PDIA) and adaptive management. ${ }^{2}$ DFID's recent review of their efforts to integrate politics into programming, for example, highlighted the organisation's commitment to this way of working (Piron, Baker, Savage, \& Wiseman, 2016), and it remains at the heart of its approach to governance programming. The focus on politics and power in the 2017 World Development Report (World Bank, 2017) and the introduction of applied political economy analysis (PEA) in USAID missions since 2014 (Garber, 2014; Rocha Menocal et al., 2018) are further examples of the growing interest in TWP in other donors.

Scholars have advocated for greater flexibility, learning from failure and paying attention to political context in aid programmes since at least the 1960s (Carothers \& de Gramont, 2013), while calls to adopt a more adaptive, locally-led approach also have a strong precedent in development theory, with a particular group of authors in the 1980s championing this philosophy (Korten, 1980; Rondinelli, 1983; Therkildsen, 1988). While 'TWP' does not therefore describe an entirely new set of ideas or methods, it is nevertheless clear that we are witnessing an unprecedented level of interest in engaging with power and politics in development organisations. An international TWP Community of Practice ${ }^{3}$-bringing together leading experts from donor agencies, NGOs, the private sector, think tanks and academia-has been meeting periodically since late 2013 , with a 'sister' DDD group meeting periodically since $2014 .{ }^{4}$ Several case studies have been published (discussed in more detail below). However, despite this growing interest in TWP among development organisations, a crucial issue that has received less attention is the extent to which adopting the ideas and practices associated with TWP have succeeded in improving the effectiveness of development programmes. In other words, does the existing evidence suggest that TWP has led to increased aid effectiveness?

This article considers this question by reviewing the current evidence base on TWP to better understand its contribution to the aid effectiveness agenda in order to inform discussions around what may constitute good practice and what future evidence needs may be. In part it uses the framework suggested by Dasandi, Marquette and Robinson (2016) to more systematically evaluate the current evidence base across three areas-political settlement, sector and organization-to see if different patterns emerge and if more fine-grained lessons for specific contexts can be found. To do this, we reviewed 44 case studies and compared them across their political context, sector and organisation.

The approach used to select this sample of case studies was based on identifying experts through the authors' professional networks and through the TWP Community of Practice mailing list, who were asked to provide relevant case studies. This was further supplemented by searching Google and Google Scholar using various combinations of relevant key words ${ }^{5}$. The sample was limited to studies that look at development practice through a lens or framework where TWP is a central part of the analysis, strategy, partnerships or design. It is not limited to a particular definition of TWP or focused only on a par-

\footnotetext{
${ }_{1}^{1}$ Pycroft also refers to 'acting politically' to differentiate between activities with a specifically political objective and 'working politically', as described here. Carothers and de Gramont (2013) talk about 'thinking and acting politically'. For whatever reason, this distinction-which is important-does not seem to have been picked up in the wider literature.

${ }^{2}$ For useful discussions of the similarities and differences between these various initiatives, see Parks (2016) and Green (2016).

${ }^{3}$ See Thinking and Working Politically Community of Practice (n.d.). The authors of this article have all played some role in the TWP Community of Practice and associated groups, albeit with varying degrees of formal involvement. Heather Marquette and Mark Robinson were founding members, and Heather was the Community's Secretary from 2013 until 2018. She remains a member of the steering committee. In 2017-18, Ed Laws was appointed as a Research Fellow to undertake research and analysis for the Community of Practice. Some of the work he undertook during the fellowship has contributed to this article. Niheer Dasandi has not had a formal role with the Community but has been a participant in several workshops.

${ }^{4}$ While the DDD website no longer exists, details can be found on ODI and Building State Capability websites. See, for example, Building State Capability (2014) and DDD Manifesto (n.d.).

5 While not a systematic review, we tried to be as systematic in our approach as possible. We used keyword terms and Boolean operators, as well as UK and US/Australian spelling. These search strings included, for example: 'TWP' AND 'development' OR 'aid' OR 'donor' OR 'programme' OR 'programming' OR 'program'; 'thinking and working politically'; 'thinking and working politically' AND 'development' OR 'aid' OR 'donor'; 'politically-informed' AND 'programme' OR 'programming' OR 'program'; 'politically-smart' AND 'programme' OR 'programming' OR 'program' OR 'donor' OR 'development'; 'adaptive' AND 'management' OR 'programming' OR 'program' OR 'aid' OR 'donor' OR 'development'; 'political economy' AND 'donor'; OR 'aid' OR 'development'; political economy analysis'; 'PEA'; ‘PDIA'; 'doing development differently'; 'DDD'.
} 
ticular approach and takes authors who self-identify as writing about TWP (or, in some cases, 'adaptive management') at face value. From the sampling, a database of available case studies was created (see Appendix). ${ }^{6}$ In addition to these cases, we also refer to more conceptual literature, as well as conversations that have taken place through blogs and online commentary. This is important for trying to understand what is, as we discuss, in many ways an ongoing conversation rather than an attempt at producing a rigorous evidence exercise.

It is important to note that in limiting our sample of studies that have an explicit TWP focus, our analysis does not consider studies that in fact do fit descriptions of 'TWP', but do not self-identify as 'TWP'. Such studies have not been included due to time and budget constraints. In this same vein, we are not reviewing case studies on the effectiveness of public sector reforms and/or development interventions in general, which would be well beyond the scope of this article. Therefore, our claims regarding the state of the evidence should be understood to refer to the literature that makes a direct link to TWP rather than the wider literature on development programmes that include elements of politically informed practice, but do not explicitly label them as such. Having said this, given that the studies included in our sample have an explicit focus on TWP, we would expect these to provide the strongest evidence on how TWP impacts aid effectiveness. Furthermore, as the cumulative knowledge produced by TWP 'identifiers' is clearly influencing development practice, trying to understand the strength of this particular evidence base remains important.

Much has been written about how prevailing organisational cultures, incentives and structures in most development agencies, as well as political pressure from ministers, continue to pose significant obstacles to the implementation of more politically informed development work (Carothers \& De Gramont, 2013; Unsworth, 2015; Yanguas, 2018; Yanguas \& Hulme, 2015). Our argument here is not that these obstacles are directly linked to a lack of evidence, or even that a stronger evidence base will, by itself, overcome these obstacles. However, a stronger evidence base that demonstrates clearly and robustly that TWP contributes to more effective development practice and, importantly, improved outcomes would certainly strengthen the case for donors to adopt more politically informed, adaptive approaches to development assistance, and as such could contribute to efforts to overcome these challenges. Our analysis suggests, however, that this strong evidence base does not yet exist.

\section{What Does the Evidence Base Currently Look Like?}

In this section, we examine the evidence base on TWP. We begin by discussing the factors identified in the existing studies as contributing to increased aid effective- ness. We then map out the evidence base on TWP. To do this, we utilise the framework proposed by Dasandi et al. (2016) that involves three levels of analysis: 1) the wider political context of development interventions-how the political system, leadership and the nature of the political settlement in a given context affect development programmes; 2) the sectoral level-how characteristics of specific sectors (e.g. health, education, or water delivery) influence programme implementation and impact; and 3) the organisational level-how features of an implementing organisation can support or hinder politically informed programming. In each section below, we provide an overview of the level of analysis and the overall evidence base within that, as well as an illustrative example of a programme that reflects that particular level of analysis. These cases were chosen as 'typical' examples to illustrate the wider body of literature (Gerring, 2008). Of course, this approach has limitations; as Seawright and Gerring (2008, p. 294) explain: 'the chosen case is asked to perform a heroic role: to stand for (represent) a population of cases that is often much larger than the case itself'. This is not, however, untypical in small- $N$ samples, and we would not claim that the illustrative cases are somehow representative of the wider reform literature. They are, however, fairly representative of the much more limited sample of TWP case studies, the subject of this article.

Although TWP is not a formal method or operational model, the literature highlights several recurring factors that are said to contribute to the success of more politically-informed programmes. Common success factors flagged by the authors are:

- Leaders were politically smart and could use that knowledge effectively;

- Programme managers allowed local actors to take the lead;

- The programmes adopted an 'iterative problem solving, stepwise learning' process;

- Programme staff brokered relationships with major interest groups;

- Donors provided flexible and strategic funding;

- There was a long-term commitment by donors and high level of continuity in staffing;

- There was a supportive environment in the donor agency.

Each of the factors listed above maps onto what are said to be corresponding weaknesses in more conventional programming approaches. For example, the imperative to be 'politically smart' contrasts with what is seen as the failings of 'politically blind' approaches to development. Similarly, the importance of local ownership is a response to problems that have been seen to emerge from development initiatives largely driven by external actors. We discuss these factors in more detail below.

\footnotetext{
${ }^{6}$ The full list of programmes can be found in Laws and Marquette (2018, pp. 37-38). We have also included a table that provides an overview of the 44 studies in the Appendix to this article.
} 
Each of the case studies that we identified included a selection of the above factors in their explanation for the programme's success, albeit sometimes in different combinations and with differing emphasis. It is, however, also important to note that these are the factors that were identified in Booth and Unsworth's (2014) influential article looking at seven cases of successful donor-led interventions. Given, as we discuss below, that these programmes cut across different political contexts, sectors and organisations, an important question that arises is whether these factors are actually the most important elements of the programme success that is claimed to the exclusion of other aspects, or whether these factors have been identified because Booth and Unsworth's (2014) article has been so influential that authors are now primed to look out for and emphasise the same features when evaluating programme success. In other words, does the literature suffer from 'confirmation bias', which means that it draws lessons only from cases that fit a pre-existing notion of what factors lead to more successful programme implementation and outcomes (Dasandi et al., 2016, p. 6)? ${ }^{7}$

One of our initial aims in compiling a database of TWP case studies was to identify patterns in the success factors across programmes, across the three different levels (political context, sector, and organisation). This was based on the expectation that different combinations of the recurring factors identified in the literature would be required to improve programme effectiveness in different contexts and sectors (Hudson \& Marquette, 2015 , p. 74). For example, we might expect that successfully incorporating politics and adaptive practice into programme design and implementation in the justice and security sector in a fragile and conflict-affected state means something quite different than in, say, a sanitation programme in a relatively stable country. However, our review of the current literature found little in the way of guidance on how and why different aspects of TWP may be necessary and sufficient conditions for success in different scenarios. Furthermore, we found little discussion of whether and how some factors or approaches may be inappropriate in certain contexts.

This is a significant issue, because if TWP is at its heart about illuminating contextual differences in order to move away from 'cookie cutter' best practice approaches (cf. Levy, 2014), then we would expect to see variations in programme design, implementation and outcomes. However, while different case studies have been published since Booth and Unsworth's comparative study, there is very little, if any, variation between them along these factors. Indeed, given the similarities highlighted below, it makes it difficult, if not impossible, to discern if the patterns that are beginning to emerge from comparing the various cases genuinely reflect an emerging consensus or if, in fact, it reflects growing 'group think' about the necessary programme design characteristics among
TWP insiders. Given the lack of discernible difference in the factors identified in the existing literature across the different levels, our discussion of each level focuses on the nature of the evidence in each of these areas, and on providing examples of the types of studies that exist.

\subsection{Political Context}

There are different ways to distinguish and analyse the political context in which development interventions take place, such as by reference to the political regime, the nature of political and bureaucratic leadership and interaction, or power structures such as gender, religion, ethnicity, caste and rural-urban divides. Here, we focus on the political settlement in a country to identify the different political contexts in which TWP programmes have been carried out. Political settlements analysis focuses on the power and incentives that shape the actions of key decision makers (Kelsall, 2018; Khan, 2018; Laws \& Leftwich, 2014). As such, it can enable development practitioners to distinguish meaningfully between different country contexts by identifying the kinds of issue areas, programming approaches, and potential partners with whom they are likely to have traction (Kelsall, 2018). Furthermore, the political settlements approach is closely related to the turn to TWP among donors (see Carothers \& de Gramont, 2013).

Political settlements have been defined as:

Informal and formal processes, agreements, and practices in a society that help consolidate politics, rather than violence, as a means for dealing with disagreements about interests, ideas and the distribution and use of power. (Laws \& Leftwich, 2014, p. 1)

Several typologies have been put forward to identify different types of political settlement. Synthesizing a range of approaches, Kelsall (2016) identifies three particularly common forms: (i) developmental (ii) predatory and (iii) hybrid. While these are ideal types, they identify a broad range of features that enable states to be categorised according to settlement type. Developmental states are characterised by an inclusive settlement, a high degree of coordination amongst elites and a bureaucracy that operates on largely impersonal norms. Predatory settlements tend to have exclusive settlements, spoils-driven elites and a bureaucracy with pervasive patron-client relations. Hybrid settlements sit between the two; there is a significant degree of inclusion and political contestation is for the most part peaceful, but some elites are excluded and actors may be willing to use political violence. Similarly, some elites are coordinated while others are spoils-driven, and the norms within the bureaucracy vary between elements of patronage and high-functioning 'pockets' that are largely rule-based (Wales, Magee, \& Nicolai, 2016, p. 13).

\footnotetext{
${ }^{7}$ One expert we consulted flagged that the extent to which these features may be objectively verified is another challenge. What defines a politically smart or a politically unsmart leader, for example?
} 
The existing case studies on TWP programmes are heavily weighted towards countries with hybrid political settlements (see Figure 1). This is perhaps to be expected, given that, as Kelsall (2016) points out, most countries in the developing world will have settlements of this kind, rather than exhibiting the characteristics at the other ends of the settlement spectrum (developmental or predatory). Apart from a report on the Strategic Capacity Building Initiative in Rwanda (AGI, n.d.), there are no studies on how TWP programmes have operated in political contexts characterised by developmental political settlements. Given that inclusive, coordinated, developmental states are highly rare in the developing world, this is not particularly surprising.

One example from a hybrid political settlement is the Enabling State Programme (ESP) in Nepal, a 13-year, DFID-supported programme with a budget of $f 33 \mathrm{~m}$. It sought to address issues of weak governance and social and political exclusion that research had identified as underlying causes of conflict and poor development outcomes. Booth and Unsworth $(2014$, p. 11) refer to a series of independent evaluations that point to ESP having been a major player in helping to shift the 'rules of the game' in the direction of greater social and political inclusion, as well as achieving more specific, quantifiable results. Specific examples of ESP impact cited include piloting of single treasury accounts in 38 districts (now rolled out in all 75 districts); support for the Public Service Commission that contributed to modest but positive increases in appointments of women and other excluded groups; and provision of disaggregated data and other evidence to the National Planning Commission.

During the lifespan of the programme the DFID office in Nepal is said to have taken considerable effort to become involved in and informed about local politics. This involved analysis of the underlying causes of the conflict dynamics that were unfolding at the time, including the political, economic, gender and ethnic dimensions and the impact of DFID programming. This research helped to refocus the work of the ESP team away from good governance and towards the critical conflict issues. In addition to this research and analysis, the team was able to recruit several well-informed, well-networked elite Nepali staff; the authors argue that these staff were not only politically well-informed but also skillful in navigating a charged political environment and in seizing opportunities to advance programme objectives (Booth \& Unsworth, 2014).

Predatory, exclusive, spoils-driven settlements are the second most common context in which TWP programmes have been studied. Trying to think and work in more politically engaged, experimental or entrepreneurial ways may be particularly appropriate for interventions in these kinds of challenging political contexts, given the uncertain change processes at play and the lack of prior accumulated evidence on what works (Wild, Booth, \& Valters, 2017). However, predatory settlements do not necessarily overlap with fragile or conflict-affected states, and a closer look at the spread of the evidence indicates a notable gap here in terms of TWP case studies. Of the 44 programmes that we identified as being the subject of TWP research, only seven are based exclusively in countries that are featured on the World Bank's most recent Harmonised List of Fragile Situations. Given the growing concentration of aid from major donors, including DFID and the World Bank, in fragile and conflict-affected states, a greater emphasis of TWP research efforts in violent and unstable political contexts would seem to be important given the untested nature of these ways of working. In addition, given the argument found in many of the case studies-as in the ESP one above-that effective programmes require politically well-connected staff, there has been surprisingly little analysis about how these staff are recruited, how their activities are assessed or what this may mean in practice in politically divided societies.

\subsection{Sector}

The conditions for successful programme implementation are also likely to vary according to the sector in question. This is because different sectors have specific characteristics that determine their political salience, the incentives for politicians to deliver them, the main actors and interests surrounding them and the ways that citizens can mobilise around them. In particular, the extent to which a particular sector or service is targetable, 'visible', measurable and easily credited affects the like-

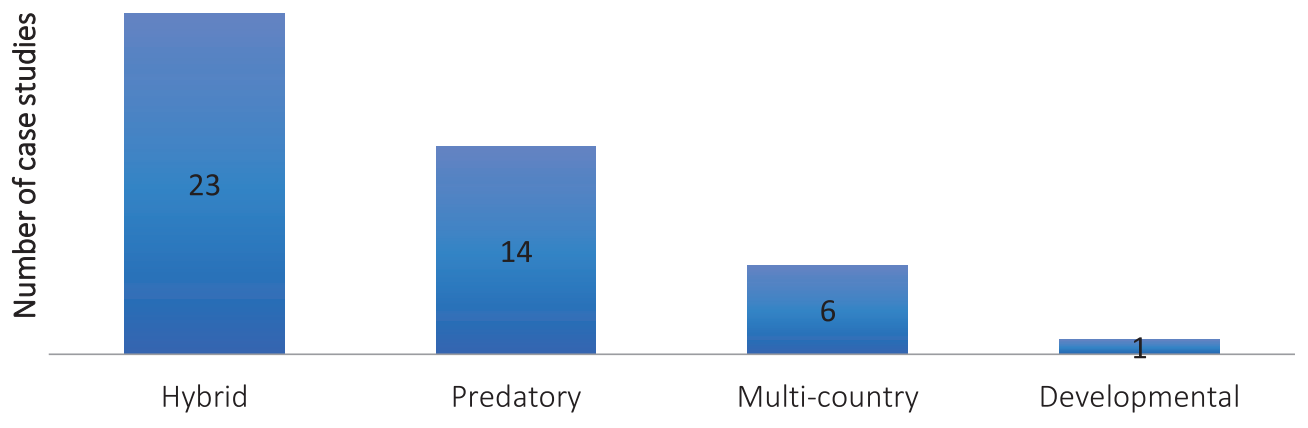

Political settlement

Figure 1. Case studies grouped according to political settlement type. 
lihood that states will be responsive to efforts to reform it (Batley \& Mcloughlin, 2015). For example, a state may have strong incentives for inclusive provision where a particular service or good has historically been a key source of state legitimacy and an expression of the social contract. Therefore, it seems reasonable to expect that programmes successfully designed and implemented with a close consideration of political dynamics would need to be aware of and responsive to the political characteristics of the sector in question.

TWP is associated closely with the governance sector, to the extent that some authors suggest that it might be trapped in a 'governance-ghetto' (Green, 2017; see also Yanguas \& Hulme, 2015). Our analysis of the evidence confirms that governance is the most heavily studied sector in the TWP field by a considerable measure (see Figure 2). One example is the Department of Foreign Affairs and Trade (DFAT)-funded Governance for Growth (GfG) programme, which has been supporting economic governance and public financial management (PFM) reforms in Vanuatu for the past decade. The programme has run over two phases at a cost of around AUD90 million over the first nine years. GfG has been able to support reforms in several different areas. Flagship changes such as the liberalisation of the telecommunications industry have been accompanied by important reforms in areas such as wharf management, fiscal decentralisation, school capitation grants and taxation.

According to a review by Hadley and Tilley (2017), GfG has been able to support these reforms by working politically, a core part of which has involved building close relationships with senior and mid-level bureaucrats in government. Many features of GfG aim to encourage close working partnerships between the GfG team and their counterparts in Vanuatu, with an office co-located in the Office of the Prime Minister. In Vanuatu, there are factors which are said to make this aspect of the initia- tive especially important. Individuals' relationships are shaped by local hierarchies and ties to family and place. Public institutions are often dominated by a particular island or church group with shared values, while status and kinship ties overlap with politics and public administration. This makes informal systems extremely important in the flow of knowledge, information and decisions (Cox et al., 2007). Building trust across groups and bridging these formal and informal systems is therefore believed to be central to supporting change in Vanuatu's public sector (Hadley \& Tilley, 2017).

In terms of the overall evidence base, there are individual studies that are spread across a very wide range of other sectors: justice and security, conflict resolution, infrastructure, gender equality, reform coalitions, PFM, investment, health, community policing, rural livelihoods, economic development, legislative reform, private sector development, state capacity, human development, water, human resources, knowledge sector, solid waste management, forestry, agriculture, and service delivery. This supports the argument made by Rocha Menocal (2014) that TWP is not simply a governance solution to be applied to a narrow set of institutional issues, because incentives and power dynamics lie at the centre of most development challenges. TWP suggests principles for improving the delivery of any aid programme that involves reform and behavioural change; therefore, it should be as relevant in principle to the better delivery of health services or economic policy reform as it is to human development or water services.

While the growing breadth of individual TWP studies across a wide range of sectors is encouraging, our review found that governance, security and justice and infrastructure are the only sectors which have been the subject of three or more case studies. In addition, with few exceptions, the programmes that have been written up into case studies are all reform programmes. It

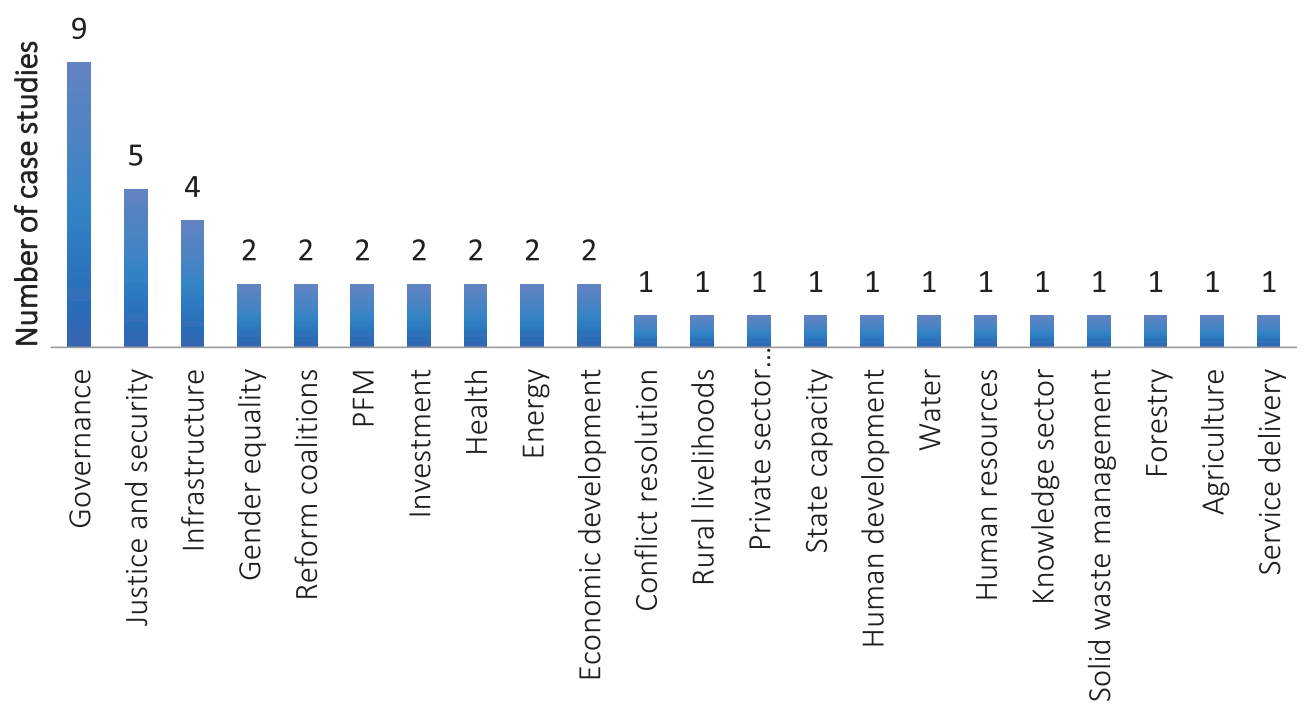

Sector

Figure 2. Case studies grouped according to sector. 
may be that the conclusion we can draw from the evidence base is that TWP might look similar, in terms of programme design, for reform programmes, regardless of sector; whether or not that is useful for someone trying to design an infrastructure programme, or a service delivery one, is not clear. It is therefore not possible to draw robust conclusions about how development programmes can think and work politically in an effective way in a particular sector without a deeper and stronger evidence base to draw upon. This would require a larger body of studies that look at a number of different programming approaches in the same sector, as well as studies looking at similar kinds of programmes in different sectors (Dasandi et al., 2016).

\subsection{Organisation}

The third level of analysis focuses on the organisations involved in the design and implementation of TWP programmes. This includes external actors (the bilateral or multilateral donors or international NGOs [INGOs] which are usually responsible for funding and programme design) and domestic partners (the government agencies and local NGOs which are typically responsible for programme implementation and aspects of design) (Dasandi et al., 2016, p. 11).

Certain kinds of organisational characteristics are claimed by the literature to be closely associated with successful TWP. For example, the TWP literature calls for organisations-and individuals within these-that can solve problems and search for workable solutions through iterative learning, can broker relationships with key stakeholders in a specific programme area and are prepared to experiment with flexible and strategic funding modalities (Booth \& Unsworth, 2014; Dasandi et al., 2016). Ideally, it is argued that organisations need to have processes in place that encourage this kind of experimentation, innovation and learning, along with a bureaucratic and managerial culture that supports staff in operating along these lines (Bain, Booth, \& Wild, 2016, p. 35).

For example, in 2012 DFAT and the Asia Foundation (TAF) began work under a strategic partnership agreement which included a range of reform initiatives that aimed to work politically in practice. In Bangladesh, the team worked with local partners to support efforts to move leather tanneries out of a dangerously polluted location to a modern industrial park. The goal was to improve compliance with health and environmental protection standards and potentially lead to growth in the sector. A reform coalition supported by TAF is said to have contributed significantly to expediting the relocation process, with figures issued in 2015 indicating that of the 155 tanneries allocated plots at the new estate, $148 \mathrm{had}$ begun substantive construction.

As detailed in an ODI case study (Harris, 2016), this initiative used structured learning to iterate and adapt over the course of implementation. This involved both regular reflective discussions as part of an approach called 'strategy testing' (Ladner, 2015), along with dayto-day, ad-hoc adjustments. Strategy testing offered opportunities for discussion within the team across all levels of seniority, and prompted staff to regularly consider how changes in the reform context might affect their strategy. The team reported that the strategy testing sessions provided an opportunity for them to take stock of recent events and actions. It also offered an opportunity to update documentation to reflect changes in the program and thereby provide a record of decisionmaking for donor accountability purposes (Harris, 2016). Micro-adjustments were also made on an on-going basis through problem solving and informally reflecting on tactics, which was encouraged by the initiative's culture.

The literature on TWP programmes focuses primarily on the role of bilateral and multilateral donors (see Figure 3). For the most part, the agencies examined are DFID, DFAT and the World Bank. Given that these donors fund a significant amount of the research that constitutes the TWP literature, this bias is not surprising, but strengthening the evidence for TWP will require researchers to look at a wider range of organisations and agents engaged in programming (Dasandi et al., 2016). There is a lack of research looking at the demands that TWP places on the internal systems, capabilities and incentive structures of the organisations implementing programmes on the ground-whether domestic or international NGOs, commercial service providers or domestic government agencies. The small number of documented cases that do focus on the experience of the implementing organisation mostly center on one INGO, the TAF, some of which were produced in collaboration with ODI, including the Bangladesh study discussed above (Denney, 2016; Faustino \& Booth, 2014; Harris, 2016; Valters, 2016). Excluding one report looking at the work of Peace Direct and Centre Résolution Conflicts in the DRC (Gillhespy \& Hayman, 2011), there appear to be no TWP studies that focus on cases where an INGO is the external funding organisation and a local NGO is the implementing partner. Finally, there are no cases at all in the sampled literature that look specifically at the experience of domestic government agencies in implementing TWP programmes with external donor support.

A more detailed insight into the internal processes involved in TWP in donor agencies is put forward in a collection of essays in Fritz, Levy and Ort (2014), which looks at the implementation of PEA in eight World Bank country programmes. These studies demonstrate how the findings and recommendations from political analysis were taken on board by different programmes and used in operational practice. As such, they provide an insight into some of the micro-level processes involved in TWP within the donor organisation and country teams. However, these studies are weaker on demonstrating how the implementation of the insights from PEA led to better outcomes or more successful programming decisions. 


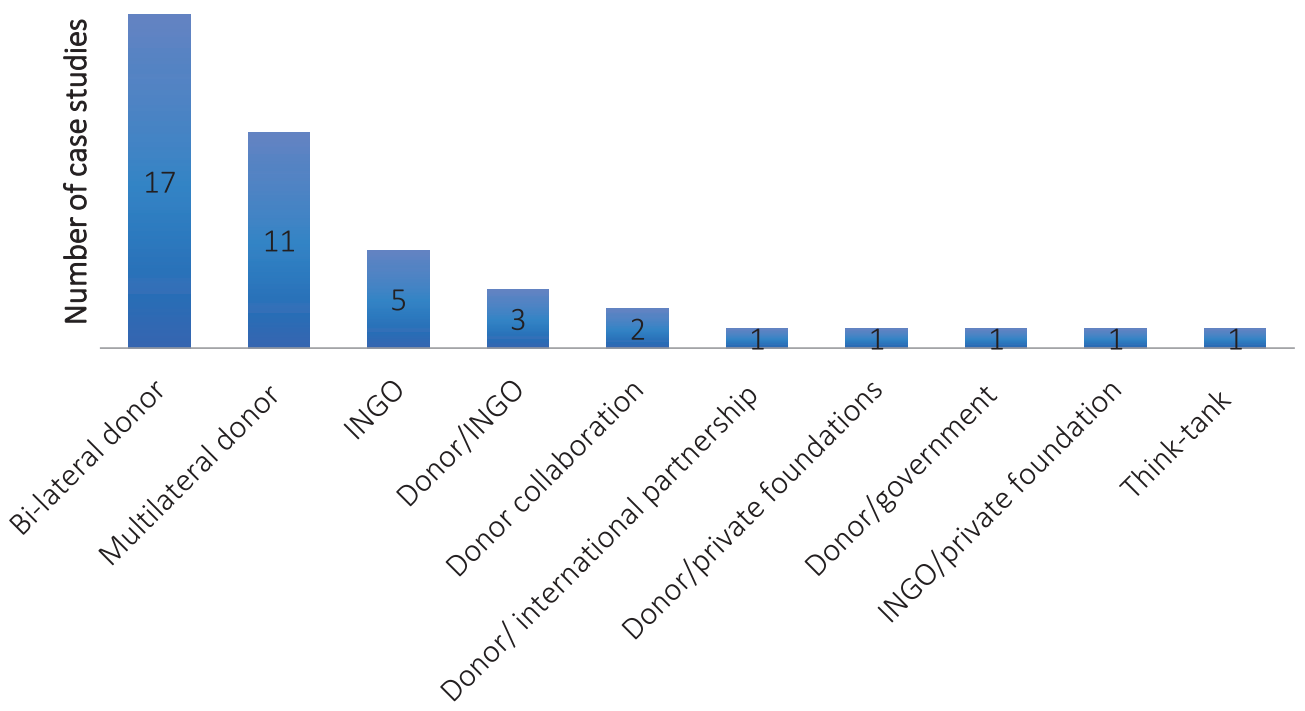

Organisation in focus

Figure 3. Case studies grouped according to organization.

\section{Is There a 'Good Enough' Evidence Base on TWP and Aid Effectiveness?}

Leading on from this, in addition to the content gaps that have been noted above, there are also important methodological limitations in the literature. These gaps and limitations mean that, while there are certainly interesting and engaging case studies, they do not constitute the kind of 'rigorous-enough' evidence base that is needed to support more ambitious causal and predictive claims about the role of TWP in improving aid effectiveness and securing better development outcomes, including in fragile environments.

With a few exceptions the case studies reviewed fall short of the high standards on transparency, validity, reliability and cogency that one would expect in a strong evidence base (DFID, 2014). The literature continues to be almost entirely made up of single programme case studies, with few attempts at comparison, and written for the most part by programme insiders. There have been recent improvements in terms of transparency on methods, most notably Denney (2016), Denney and McLaren (2016), Hadley and Tilley (2017), Harris (2016) and Lucia, Buckley, Marquette and McCulloch (2017, in press). However, even these rely largely on interviews and documentary analysis, or a form of action research, rather than methods more appropriate for establishing causal explanations. Moreover, approaches to triangulation are often unclear or entirely absent. Subsequently, in the case studies reviewed, it is often hard to discern a direct causal relationship between TWP and the outcomes that were said to have been achieved.

Only one study in our sample (Booth, 2014) considers counterfactuals and very few discuss challenges faced in the programmes or areas that were unsuccessful (no- table exceptions include Denney and Maclaren (2016), Hadley and Tilley (2017) and Lucia et al. (2017, in press). A more balanced approach would look to highlight areas where TWP has failed to achieve positive results or to achieve the results that were intended. The fact that this is uncommon in the case studies reviewed may be, at least in part, because many TWP case studies have been written up either by funders themselves or by other actors who have been involved in evaluating the programme as part of its implementation. ${ }^{8}$

This also means that there are limitations of the existing literature in terms of its theory-building rather than theory-testing potential. As we have discussed, the TWP literature identifies several factors that are seen as improving the effectiveness of politically-informed programmes, such as programme managers allowing local actors to take the lead and programme staff brokering relationships with major interest groups. However, beyond fairly broad discussions, there is a lack of in-depth analysis of how, and importantly when, these factors lead to improved outcomes. For example, programme staff brokering relationships with major interest groups by itself will not enable programme staff to address opposition to change by these groups or contestation among these different interest groups. As such, there is also a need for more attention to causal mechanisms that connect the factors identified in the literature with increased aid effectiveness. This would be helped by greater engagement with some of the more general literature on the politics of reform processes (e.g. Ascher, 1984; Grindle, 2004). In part, this again would be helped by greater engagement with programmes that have adopted elements of TWP but failed to achieve positive results.

This would seem to be particularly relevant to TWP, which emphasises the need to test theories of change

\footnotetext{
${ }_{8}^{8}$ This also raises more serious questions about the potential for conflicts of interest to arise in 'insider' driven research, especially where potential commercial benefits exist, something that has not yet been sufficiently addressed.
} 
and adapt projects and programmes in light of some activities failing. Indeed, studies rarely focus on outcomes, instead focusing on the reform and/or programming process instead. Few studies discuss their criteria for 'success', including what the relevant metrics used are. All of this raises concerns about quality, which can often be ameliorated by publishing in well regarded, peer reviewed journals as a proxy for quality. However, to the best of our knowledge, only one of the case studies has been published in a peer reviewed journal (Lucia et al., in press). While one might expect a healthy balance between organizational working papers and journal articles in such a practice-oriented area, the lack of journal articles is a concern, especially when combined with the other points raised here.

\section{Conclusions}

This article has looked at the existing evidence base for TWP with the aim of providing guidance for future research into what works, where and why in terms of TWP programming. In short, we find that while there are certainly interesting and engaging case studies in the literature, these do not yet constitute a 'strong enough' evidence base that proves that TWP has significantly improved aid effectiveness. Since TWP is a relatively recent arrival in the development debate, gaps in the literature are to be expected. Additionally, the primary function of TWP may not in fact be aid effectiveness per se, but rather avoiding the well recorded pitfalls and negative unintended consequences of 'politically blind' aid (Carothers \& de Gramont, 2013). But given the rising interest in developing more politically informed, flexible and adaptive programming, and claims that case study authors themselves make about improved effectiveness, this should be an urgent priority for funders. In addition, if one intention is to avoid the well documented consequences of 'politically blind' aid, the potential for unintended consequences to emerge from TWP 'approaches', such as relying on politically well-connected insiders, should be another urgent priority.

We suggest that-if our overall aim is to understand the effect of TWP on aid effectiveness-we need to move beyond descriptions of what are, in effect, programme designs and activities. The analysis here suggests that if we are to determine if TWP leads to greater aid effectiveness, future research should consider more rigorous and structured testing of what works, where, why and how. Ideally, this would happen while this sort of programming is still relatively 'niche' and where it does not yet make up a significant percentage of donor funding. Developing a better understanding of the approaches and strategies that work well in different political, sectoral and organisational contexts will be an important step if TWP, and its variants such as adaptive management, are going to move into more mainstream development programming. Looking at programmes in a broader range of political contexts, including in contexts that are fragile and conflict-affected, where a focus on potential unintended consequences-including from the programming approach used-and on the trade-offs and dilemmas that development organisations face, may be particularly salient in terms of engaging with the political process of development (see Dasandi \& Erez, 2017).

By systematically comparing a broader range of programmes in different sectors and organisational contexts, the field may be able to draw firmer lessons about programme implementation and outcomes in different situations, testing some of the common assumptions about what works. This will help to demonstrate whether there are general lessons about when, why, and how different factors identified in TWP literature lead to programme success or failure. This may, in turn, help the field move towards a clearer understanding of the constraints that can hinder more political ways of working and to explore where and how these barriers have occurred in the context of specific strategies, programmes or country offices. Comparative analysis could then be used to test assumptions and draw out lessons about how actors have or have not been able to navigate around them in different contexts.

\section{Acknowledgments}

We would like to thank four anonymous reviewers for their thoughtful and incredibly useful comments. We would also like to thank colleagues in the University of Birmingham's International Development Department who discussed the article as part of a research away day and, in particular, Richard Batley, Eleanor Chowns, Claire Mcloughlin and Alina Rocha Menocal, who provided substantial written comments. We are also grateful for comments from Kirsten Bishop, Diana Cammack, Lisa Denney, Peter Evans, Duncan Green, David Hudson, Sandra Kraushaar, Neil McCulloch, Thomas Parks, LaureHélène Piron, Chris Roche and Pablo Yanguas. As always, any limitations remain our own.

The research has been funded in part by UK aid from the UK government and by the Australian aid program; however, the views expressed do not necessarily reflect the UK or Australian governments' official policies.

\section{Conflict of Interests}

The authors declare no conflict of interests.

\section{References}

Africa Governance Initiative. (n.d.). Two steps at a time: Rwanda's strategic capacity building initiative. London: AGI.

Ascher, W. (1984). Scheming for the poor: The politics of redistribution in Latin America. Cambridge, MA: Harvard University Press.

Bain, K., Booth, B., \& Wild, L. (2016). Doing development differently at the World Bank: Updating the plumb- 
ing to fit the architecture. London: Overseas Development Institute.

Batley, R., \& Mcloughlin, C. (2015). The politics of public services: A service characteristics approach. World Development, 74, 275-285.

Booth, D. (2014). Aiding institutional reform in developing countries: Lessons from the Philippines (Working Politically in Practice Series, No. 1). London: Overseas Development Institute

Booth, D., \& Unsworth, S. (2014). Politically smart, locally led development. London: Overseas Development Institute.

Bourguignon, F., \& Sundberg, M. (2007). Aid effectiveness: Opening the black box. American Economic Review, 97(2), 316-321.

Building State Capability. (2014). Doing development differently. Center for International Development at Harvard University. Retrieved from https://bsc.cid. harvard.edu/doing-development-differently

Carothers, T., \& De Gramont, D. (2013). Development aid confronts politics: The almost revolution. Washington, DC: Brookings Institution Press.

Cox, M., Alatoa, H., Kenni, L., Naupa, G. R., Soni, N., \& Vatu, C. (2007). The unfinished state: Drivers of change in Vanuatu. Canberra: AusAID.

Dasandi, N., Marquette, H., \& Robinson, M. (2016). Thinking and working politically: From theory building to building an evidence base. Birmingham: Developmental Leadership Program.

Dasandi, N., \& Erez, L. (2017). The donor's dilemma: International aid and human rights violations. British Journal of Political Science.

DDD Manifesto. (n.d.). DDD Manifesto. Retrieved from https://www.odi.org/sites/odi.org.uk/files/odiassets/events-documents/5149.pdf

Denney, L. (2016). Reforming solid waste management in Phnom Penh (Working Politically in Practice Series, No. 8). London: Overseas Development Institute.

Denney, L., \& McLaren, R. (2016). Thinking and working politically to support developmental leadership and coalitions: The pacific leadership Program (Developmental Leadership Program Research Paper, No. 41). Birmingham: Developmental Leadership Program.

Department for International Development. (2014). Assessing the strength of evidence. How to note. London: Department for International Development.

Doucouliagos, H., \& Paldam, M. (2009). The aid effectiveness literature: The sad results of 40 years of research. Journal of Economic Surveys, 23(3), 433-461.

Easterly, W. (2006). The white man's burden: Why the West's efforts to aid the rest have done so much ill and so little good. Oxford: Oxford University Press.

Faustino, J., \& Booth, D. (2014). Development entrepreneurship: How donors and leaders can foster institutional change (Working Politically in Practice Series). London: Overseas Development Institute.

Ferguson, J. (1990). The anti-politics machine: "Development", depoliticization and bureaucratic power in
Lesotho. Cambridge: Cambridge University Press.

Fritz, V., Levy, B., \& Ort, R. (2014). Problem-driven political economy analysis: The World Bank's experience. Washington, DC: World Bank.

Garber, L. (2014). Thinking and working politically. USAID Impact Blog. Retrieved from https://blog.usaid.gov/ 2014/02/thinking-and-working-politically

Gerring, J. (2008). Case selection for case study analysis: Qualitative and quantitative techniques. In J. BoxSteffensmeier, H. Brady, \& D. Collier (Eds.), The Oxford handbook of political methodology. Oxford: Oxford University Press.

Gillhespy, T., \& Hayman, C. (2011). Coming home: A case study of community led disarmament, demobilisation and reintegration in D. $R$. Congo. London: Peace Direct.

Green, D. (2016). Where have we got to on adaptive learning, Thinking and working politically, doing development differently etc? Getting beyond the people's front of Judea. Oxfam from Poverty to Power Blog. Retrieved from https://oxfamblogs.org/fp2p/ where-have-we-got-to-on-adaptive-learningthinking-and-working-politically-doing-development -differently-etc-getting-beyond-the-peoples-front-ofjudea

Green, D. (2017). Thinking and working politically: where have we got to?. Oxfam from Poverty to Power Blog. Retrieved from https://oxfamblogs.org/ $\mathrm{fp} 2 \mathrm{p} /$ thinking-and-working-politically-where-havewe-got-to

Grindle, M. S. (2004). Despite the odds: The contentious politics of education reform. Princeton, NJ: Princeton University Press.

Hadley, S., \& Tilley, H. (2017). Governance for growth in Vanuatu: Review of a decade of Thinking and working Politically. London: Overseas Development Institute.

Harris, D. (2016). Leather sector reform in Bangladesh (Working Politically in Practice Series, No. 7). London: Overseas Development Institute.

Hudson, D., \& Dasandi, N. (2014). The global governance of development: Development financing, good governance, and the domestication of poverty. In A. Payne \& N. Phillips (Eds), Handbook of the international political economy of governance. Cheltenham: Edward Elgar.

Hudson, D., \& Marquette, H. (2015). Mind the gaps: What's missing in political economy analysis and why it matters. In A governance practitioner's notebook: Alternative ideas and approaches. Paris: OECD.

Kelsall, T. (2016). Thinking and working with political settlements. London: Overseas Development Institute.

Kelsall, T. (2018). Towards a universal political settlement concept: A response to Mushtaq Khan. African Affairs, 117(469), 656-669.

Khan, M. (2018). Political settlements and the analysis of institutions. African Affairs, 469(1), 636-655.

Korten, D. C. (1980). Community organization and rural development. A learning process approach. Public 
Administration Review, 40(5), 480-511.

Ladner, D. (2015). Strategy testing: An innovative approach to monitoring highly flexible aid programs (Working Politically in Practice Series, No. 3). London: Overseas Development Institute.

Laws, E., \& Leftwich, A. (2014). Political settlements (Developmental Leadership Program, Concept Brief No. 1). Birmingham: Developmental Leadership Program.

Laws, E., \& Marquette, H. (2018). Thinking and working politically: Reviewing the evidence on the integration of politics into development practice over the past decade. University of Birmingham: Thinking and working politically Community of Practice.

Leftwich, A. (2000). States of development: On the primacy of politics in development. London: Polity.

Leftwich, A. (2011). Thinking and working politically: What does it mean? Why is it important? And how do you do it? Birmingham: Developmental Leadership Program.

Levy, B. (2014). Working with the grain: Integrating governance and growth in development strategies. Oxford: Oxford University Press.

Lucia, E. L., Buckley, J., Marquette, H., \& McCulloch, N. (2017). Thinking and working politically: Lessons from FOSTER in Nigeria (Developmental Leadership Program Research Paper, No. 48). Birmingham: Developmental Leadership Program.

Lucia, E. L., Buckley, J., Marquette, H., \& McCulloch, N. (in press). Lessons from Nigeria for improved thinking and working politically in the extractives sector. Development Policy Review.

Parks, T. (2016). Fragmentation of the thinking and working politically agenda: Should we worry? Developmental Leadership Program. Retrieved from http://www.dlprog.org/opinions/fragmentationof-the-thinking-and-working-politically-agendashould-we-worry.php

Piron, L. H., Baker, A., Savage, L., \& Wiseman, K. (2016). Is DFID getting real about politics? A stock take of how DFID has adopted a politically-informed approach (2010-2015). London: Department for International Development.

Pycroft, C. (2006). Addressing the political dimensions of development (Asia Development Bank: The Governance Brief, No. 14). Mandaluyong: Asia Development Bank.

Pycroft, C. (2010). Working politically: What does it mean? (Department for International Development, internal discussion paper). London: Department for International Development.

Rocha Menocal, A. (2014). Getting real about politics: From thinking politically to working differently. London: Overseas Development Institute.

Rocha Menocal, A., Cassidy, M., Swift, S., Jacobstein, D., Rothblum, C., \& Tservil, I. (2018). Thinking and working politically through applied political economy analysis: A guide for practitioners. Washington, DC: USAID.

Rondinelli, D. (1983). Implementing decentralization programmes in Asia: A comparative analysis. Public Administration and Development, 3(3), 181-207.

Seawright, J., \& Gerring, J. (2008). Case selection techniques in case study research: A menu of qualitative and quantitative options. Political Research Quarterly, 61(2), 294-398.

Tarp, F., \& Hansen, H. (2003). Aid effectiveness disputed. In H. Hansen \& F. Tarp (Eds). Foreign aid and development: Lessons learnt and directions for the future. London: Taylor and Francis.

Teskey, G. (2017). Thinking and working politically: Are we seeing the emergence of a second orthodoxy? (ABT Associates, Governance Working Paper Series, Issue 1). Cambridge, MA: ABT Associates

Therkildsen, O. (1988). Watering white elephants? Lessons from donor funded planning and implementation of rural water supplies in Tanzania. Uppsala: Scandinavian Institute of African Studies.

Thinking and Working Politically Community of Practice. (n.d.). Thinking and working politically. Retrieved from https://twpcommunity.org

Thinking and Working Politically Community of Practice. (2013). The case for Thinking and working politically: the implications of 'doing development differently'. Retrieved from http://publications.dlprog.org/TWP. pdf

Unsworth, S. (2009). What's politics got to do with it? Why donors find it so hard to come to terms with politics, and why this matters. Journal of International Development, 21(6), 883-894.

Unsworth, S. (2015). It's the politics! Can donors rise to the challenge? In A governance practitioner's notebook: Alternative ideas and approaches. Paris: OECD.

Valters, C. (2016). Building justice and peace from below? Supporting community dispute resolution in Asia (Working Politically in Practice, No. 9). London: Overseas Development Institute.

Wales, J., Magee, A., \& Nicolai, S. (2016). How does political context shape education reforms and their success? (Overseas Development Institute, Dimension Paper, 6). London: Overseas Development Institute.

Wild, L., Booth, D., \& Valters, C. (2017). Putting theory into practice: How DFID is doing development differently. London: Overseas Development Institute.

World Bank. (2017). World Development Report 2017: Governance and the law. Washington, DC: The World Bank.

Yanguas, P. (2018). Why we lie about aid. London: Zed Books.

Yanguas, P., \& Hulme, D. (2015). Barriers to political analysis in aid bureaucracies: From principle to practice in Department for International Development and the World Bank. World Development, 74, 209-219. 


\section{About the Authors}
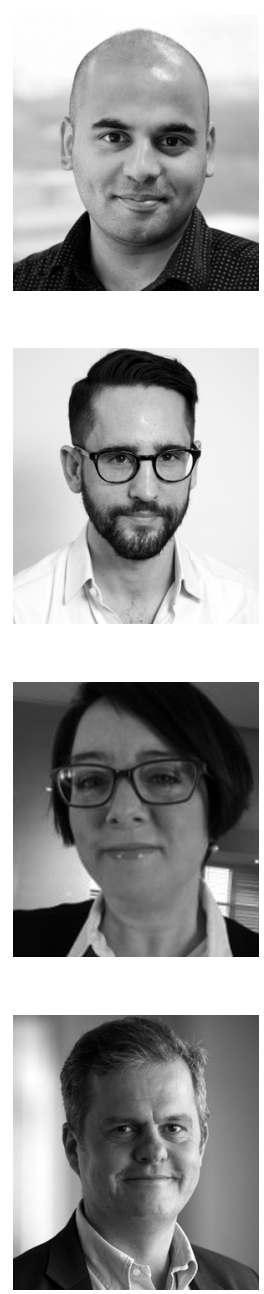

Niheer Dasandi is a Lecturer and Birmingham Fellow at the University of Birmingham. His research focuses on the connections between international and domestic politics, particularly on issues related to international development, human rights, and climate change. His work has been published in leading academic journals, including the British Journal of Political Science, The Lancet, and New Political Economy. He completed a PhD in Political Science from University College London in 2013, and previously worked for the United Nations Development Programme.

Ed Laws is a Senior Research Officer at the Overseas Development Institute. He previously worked as a researcher for the Developmental Leadership Program (DLP) and the University of Birmingham. He is a DLP associate and a former Research Fellow with the TWP Community of Practice. He specialises in political economy and political settlements analysis, and has a particular interest in politically smart approaches to aid delivery, flexible and adaptive programming, and the politics of service delivery.

Heather Marquette is Professor in Development Politics at the University of Birmingham's International Development Department, and Senior Research Fellow (Governance \& Conflict) at DFID. She has extensive international experience in research, policy advice and training on the politics of development, governance, corruption, political analysis and aid policy. Her research includes work on Afghanistan, Ghana, India, Kenya, Nigeria, South Africa and Uganda and has been published in Governance, Third World Quarterly, Political Studies, and Public Administration \& Development, among others. She writes here in her personal capacity.

Mark Robinson is the Executive Director of the EITI since 2018, leading the organisation's engagement on extractives transparency and managing the International Secretariat. He is a political scientist with over 30 years of international leadership experience in governance, climate and international development, spanning the worlds of policy-making, research and philanthropy. Mark joined the EITI from the World Resources Institute, where he served as global director for the Governance Center. In earlier years, Mark held senior posts at the Department for International Development, the Institute of Development Studies, the Ford Foundation and the Overseas Development Institute. He has held numerous board and advisory roles, and currently serves as Board Chair of the Open Government Partnership Secretariat. He writes in his personal capacity. 
Appendix. List of case studies.

\section{Programme}

Australia-Timor-Leste Partnership

for Human Development

Budget Strengthening Initiative

\section{Donor/lead organisation Country \\ DFAT Timor-Leste}

DFID, AusAID, DANIDA, South Sudan, Sierra Leone, Liberia, World Bank
Democratic Republic of Congo and Uganda, the Secretariat of the $\mathrm{g} 7+$ based in Timor-Leste

\begin{tabular}{|c|c|c|}
\hline Centre for Inclusive Growth & DFID & Nepal \\
\hline Coalitions for Change & DFAT-TAF & Philippines \\
\hline Community Dispute Resolution & TAF & Philippines \\
\hline Community Dispute Resolution & $\begin{array}{l}\text { TAF, Hewlett Foundation } \\
\text { \& later USAID }\end{array}$ & Nepal \\
\hline Community Dispute Resolution & TAF & Sri Lanka \\
\hline Community Policing & TAF, DFID \& BHC & Sri Lanka \\
\hline Community Policing & TAF & Timor-Leste \\
\hline Developing Commercical Agriculture & World Bank & Ghana \\
\hline $\begin{array}{l}\text { Disarmament, Demobilisation } \\
\text { and Reintegration in DRC }\end{array}$ & Peace Direct & DRC \\
\hline $\begin{array}{l}\text { Empowerment, Voice and Accountability } \\
\text { for Better Health and Nutrition }\end{array}$ & DFID & Pakistan \\
\hline Energy Subsidy Reform & World Bank & Morocco \\
\hline $\begin{array}{l}\text { EU Forest Law Enforcement, Governance } \\
\text { and Trade Action Plan }\end{array}$ & EU, DFID & Asia, Africa, Central and South America \\
\hline Facility for Oil Sector Transparency and Reform & DFID & Nigeria \\
\hline Governance for Development & DFAT & Timor-Leste \\
\hline Governance for Growth & DFAT & Indonesia \\
\hline Governance for Growth in Vanuatu & DFAT & Vanuatu \\
\hline $\begin{array}{l}\text { Health sector quality improvement projects } \\
\text { ('basket' case study) }\end{array}$ & Multiple donors & Ghana, Ethiopia \\
\hline Infrastructure Reform & World Bank & Sierra Leone \\
\hline Infrastructure Reform & World Bank & Zambia \\
\hline Knowledge Sector Initiative & $\begin{array}{l}\text { DFAT/Government } \\
\text { of Indonesia }\end{array}$ & Indonesia \\
\hline Leather Sector Initiative & DFAT, TAF & Bangladesh \\
\hline Legal Assistance for Economic Reform & DFID & $\begin{array}{l}\text { Kenya, Rwanda, Sierra Leone, Somaliland, } \\
\text { Uganda, Bangladesh, Burma, Tanzania }\end{array}$ \\
\hline $\begin{array}{l}\text { Local government development programmes } \\
\text { ('basket' case study) }\end{array}$ & UNCDF & Uganda \\
\hline Local Infrastructure in Papua New Guinea & World Bank & PNG \\
\hline Pacific Leadership Program & DFAT & $\begin{array}{l}\text { Pacific region with a focus on Samoa, } \\
\text { Solomon Islands, Tonga and Vanuatu }\end{array}$ \\
\hline Pacific Women Shaping Pacific Development & DFAT & Fiji, Kiribati, Papua New Guinea and Tonga \\
\hline Papua New Guinea Governance Facility & DFAT & PNG \\
\hline
\end{tabular}


COGITATIO

\begin{tabular}{|c|c|c|}
\hline Programme & Donor/lead organisation & Country \\
\hline Pay and Attendance Monitoring Programme & DFID, Global Fund & Sierra Leone \\
\hline Private Sector Development & DFID & DRC \\
\hline Pyoe Pin & DFID, SIDA, DANIDA & Myanmar \\
\hline Reforming Solid Waste Management & DFAT/TAF & Cambodia \\
\hline Rural Water and Accountability Programme & $\begin{array}{l}\text { DFID, SNV Netherlands } \\
\text { Development Organisation }\end{array}$ & Tanzania \\
\hline Shifting Incentives in the Power Sector & World Bank & Dominican Republic \\
\hline State Accountability and Voice Initiative & DFID & Nigeria \\
\hline $\begin{array}{l}\text { State Partnership for Accountability, } \\
\text { Responsiveness and Capability }\end{array}$ & DFID & Nigeria \\
\hline Strategic Capacity Building Initiative & UNDP, World Bank & Rwanda \\
\hline Strategy and Policy Unit & $\begin{array}{l}\text { Various private foundations } \\
\text { and institutional donors }\end{array}$ & Sierra Leone \\
\hline $\begin{array}{l}\text { Strengthening Local Service Delivery in } \\
\text { the Philippines }\end{array}$ & World Bank & Philippines \\
\hline The Enabling State Programme & DFID & Nepal \\
\hline Voices for Change & DFID & Nigeria \\
\hline Western Odisha Rural Livelihoods Programme & DFID & India \\
\hline World Bank Country Assistance Strategy & World Bank & Mongolia \\
\hline
\end{tabular}

